ORIGINAL ARTICLE

\title{
Biological resistance and wettability of particleboard produced with sugarcane waste
}

\author{
Resistência biológica e molhabilidade de painéis aglomerados produzidos \\ com bagaço de cana-de-açúcar
}

\author{
Flávia Maria Silva Brito ${ }^{1}$ (D) Geraldo Bortoletto Júnior ${ }^{1}$ (D) , Juarez Benigno Paes $^{2}$ (D) \\ ${ }^{1}$ Escola Superior de Agricultura "Luiz de Queiroz" - ESALQ, Universidade de São Paulo - USP, Piracicaba, SP, Brasil \\ Universidade Federal do Espírito Santo - UFES, Jerônimo Monteiro, ES, Brasil
}

\begin{abstract}
How to cite: Brito, F. M. S., Bortoletto Júnior, G., \& Paes, J. B. (2021). Biological resistance and wettability of particleboard produced with sugarcane waste. Scientia Forestalis, 49(129), e3309. https://doi.org/10.18671/scifor.v49n129.07
\end{abstract}

\begin{abstract}
This work aimed to evaluate the particle chemical compositions, biological resistance and wettability of sugarcane particleboard. Panels with 0.50 and $0.85 \mathrm{~mm}$ particle sizes were treated and untreated in hot water (control) and glued with urea formaldehyde resin with $10 \%$ solids in relation to the dry particle mass. Three rotting fungi were tested: two white rots and one brown rot. Two solvents were used for the wettability (water and ethylene glycol). Chemical analysis of treated and control particles was performed. The results obtained for the chemical analysis evidenced a decrease in total extractive contents due to the treatment in hot water. Panels manufactured with control particles and having greater granulometry exhibited improvements in resistance to $G$. trabeum and $T$. versicolor fungi. All tested panels were classified as moderately resistant. The contact angles (wettability) obtained with the solvents were not influenced by the treatments, and the panel surfaces were classified as non-wetting and partially wetting.

Keywords: Chemical analysis of particles; Rotting fungi; Mass loss; Contact angle.

\section{Resumo}

O objetivo do trabalho foi avaliar a composição química das partículas, a resistência biológica e molhabilidade de painéis de partículas de bagaço de cana encoladas com resina à base de ureia formaldeído. Foram produzidos painéis com duas granulometrias de partículas (0,50 e 0,85 mm), tratadas e não tratadas em água quente (controle) e encolados com resina a base de ureia formaldeído (UF), com $10 \%$ de sólidos em relação à massa das partículas. Para avaliar a resistência biológica dos painéis foram realizados ensaios com três fungos apodrecedores, um de podridão branca e dois de podridão parda. Para a molhabilidade foram utilizados dois solventes: água e etilenoglicol. Realizou-se a análise química das partículas tratadas e não tratadas (controle). Os resultados obtidos para a análise química evidenciaram uma tendência de redução dos teores de extrativos totais, devido ao tratamento em água quente. Painéis manufaturados com partículas controle e de maior granulometria exibiram melhorias significativas na resistência aos fungos, $G$. trabeum e $T$. versicolor. Todos os painéis testados foram classificados como moderadamente resistentes. Os ângulos de contato (molhabilidade) obtidos com os solventes não foram influenciados pelos fatores testados e, as superfícies dos painéis foram classificadas como não molhante e parcialmente molhante.
\end{abstract}

Palavras-chave: Análise química de partículas; Fungos apodrecedores; Perda de massa; Ângulo de contato.

Financial support: None.

Conflict of interest: Nothing to declare.

Corresponding author: faengflorestal@gmail.com

Received: 13 March 2019.

Accepted: 4 September 2019.

Editor: Paulo Henrique Müller Silva.

(c) This is an Open Access article distributed under the terms of the Creative Commons Attribution License, which permits unrestricted use, istribution, and reproduction in any medium, provided the original work is properly cited. 


\section{INTRODUCTION}

The main raw material used for manufacturing reconstituted panels in Brazil comes from forest plantations (Vital et al., 2014) of pine and eucalyptus, and generates a good quality product because of the homogeneity control of these plantations (Fiorelli et al., 2013). Parallel to this, the sugarcane agroindustry is fully established and growing in the country. In the last decades, the sugarcane industry has shown a great capacity to add value to alcohol and sugar co-products such as vinasse (as fertilizer), filter cake, straw (energy generation) and bagasse (industrial raw material, animal feed and energy generation) (Meschede et al., 2012).

The sugar-energy industry, being an agro-industrial activity, is directly influenced by an intrinsic characteristic: the seasonality of the production of the raw material. Seasonal production dissociates the harvest period, which is concentrated in a few months of the year crop, from the needs of consumption that continue throughout the months of the year. In practice, it is necessary to build stocks at the time of harvest to regularize the supply, particularly during the off-season, when the distilleries are off and there is no production (Bressan Filho, 2010).

The sugar-alcohol sector, being an agro-industrial activity, is directly influenced by an intrinsic characteristic: the seasonality of the production of the raw material. Seasonal production dissociates the harvest period, which is concentrated in a few months of the crop year, from the needs of consumption that continue throughout the months of the year. In practice, it is necessary to build stocks at the time of harvest to regularize the supply, particularly during the off-season, when the distilleries are off and there is no production (Bressan Filho, 2010).

Among the listed uses, some research points to the promising use of sugarcane bagasse, waste from the sugarcane milling process, as a material which can be used in manufacturing particleboard panels (Belini et al., 2010; Barros Filho et al., 2011; Fiorelli et al., 2011, 2013; Castro Júnior et al., 2014; Mendes et al., 2014; Silva et al., 2017; Soares et al., 2017).

In order to use sugarcane waste as raw material in producing particleboard panels, it is important to highlight the value added to it, in addition to meeting the demand of the panel industry, and which may further lead to a reduction in production costs and consequently make the sector more competitive in the global economic scenario (Mendes et al., 2012).

Studies point to the technical feasibility of its use for the production of particleboard, as is already the case in other countries, such as Cuba, Colombia, China, Argentina and Russia. The panels have, among other characteristics, ease in the machining and good gluing in the assembly of pieces of furniture. They have, however, basic constituents highly susceptible to the attack of xylophagous organisms (Teixeira et al., 1997). There is no evidence on the production of particleboard made from sugar cane bagasse manufactured in Brazil.

After the milling process, the amount of waste produced depends on the fiber content of the processed sugarcane, which has on average $48-52 \%$ moisture, $46-48 \%$ insoluble solids (fibers and other anatomical elements), and $2-3 \%$ of soluble materials, thus resulting in approximately 280 kilos of waste per ton of processed sugarcane (Hassuani, 2005). Sugarcane waste has characteristics such as high carbohydrate concentration, low relative lignin content, ease of use, and low cost of harvest, transport and storage, which facilitate its use (Pandey et al., 2000).

The chemical composition of the waste is variable according to some parameters such as cane variety, soil, harvesting and handling techniques (Silva et al., 2007). The waste basically consists of cellulose, hemicellulose and lignin. The first two constituents form a systematic arrangement embedded by lignin (Rodrigues \& Peixoto, 1993), as well as extractives. The waste washing process is capable of removing soluble inorganic compounds and residual sucrose which may be present after milling the sugarcane and extracting the juice (Pitarelo, 2013).

These compounds may influence some characteristics of the lignocellulosic material such as color, smell, permeability, density, hardness and biological resistance (Pettersen, 1984). The main biological agents that attack wood are fungi and can be classified as mold, stain and rot 
(Stangerlin et al., 2013). Particle boards that exhibit high biological resistance to these organisms can be highlighted by the broad spectrum of use, hence making them more valued (Stangerlin et al., 2011).

Another point that deserves to be highlighted in relation to the technological characterization of particleboard panels is wettability, which can be characterized by contact angle measurements. Good wetting is essential in the adhesion process as it will ensure better mechanical interactions at the molecular level and secondary forces between the varnish and the surface of the material (Hernández \& Cool, 2008). Complete characterization of the technological variables of the panels in relation to the tests that refer to defining usage classes, final applicability of the products and prevention methods are important for the quality of the panels (Okino et al., 2007).

Thus, the objective of this work was to evaluate the chemical composition of the particles, the biological resistance and wettability of particleboard made from sugarcane waste particles bonded with urea formaldehyde-based resin.

\section{MATERIAL AND METHODS}

\section{Collection of sugarcane waste}

The sugarcane waste used in producing the particleboard was collected in the stockyard of a sugar mill, located in Santa Barbara D'Oeste, state of São Paulo, Brazil. During the collection, waste free from traces of deterioration and uniform coloration was selected.

The material was transported to the Laboratory of Lamination and Wood Panels of the Luiz de Queiroz College of Agriculture, University of São Paulo, Piracicaba, São Paulo, Brazil, where it was spread on a plastic canvas and exposed to the open air for drying until it reached a moisture content close to $18 \%$.

Drying was complemented in an oven, maintained at a temperature of $70 \pm 2^{\circ} \mathrm{C}$, until reaching an average moisture content of $10 \%$. The waste was classified in a set of vibrating screens with different mesh openings $(5.66,4.00,2.00,0.85$ and $0.50 \mathrm{~mm})$, in addition to a collecting tray. The upper sieves retain the material having larger dimensions and the lower sieves having smaller sieves retain the smaller particles which are more suitable for the manufacture of panels, for this reason the granules were of 0.50 and $0.85 \mathrm{~mm}$.

\section{Treatment of the particles by immersion in hot water}

The treatment of the particles in hot water was carried out with the aim to remove soluble materials from the sugarcane waste, which could negatively interfere in the panel properties, such as adhesion quality and fungus durability. Thus, a suitable portion of waste particles with particle sizes of $0.85 \mathrm{~mm}$ and $0.50 \mathrm{~mm}$ were treated in hot water.

For the immersion treatment of the particles, a structure in iron bars $\left(5 / 16^{\prime \prime}\right)$ was constructed with dimensions of $63 \times 30 \times 83 \mathrm{~cm}$ (width $\times$ height $\times$ length), which was lined with a double layer of sombrite ${ }^{\circledR}$ to avoid dispersion of the material when immersed. The structure was immersed in hot water in a metal tank, with dimensions of $1.2 \times 0.70 \times 1.5 \mathrm{~m}$ (width $\mathrm{x}$ height $x$ length), equipped with a set of electric resistors and thermostat, regulated to maintain the temperature of the liquid at $70 \pm 5^{\circ} \mathrm{C}$.

The ratio of particle mass and volume of water used in each treatment was $7 \cdot 5: 1.17$. The box remained immersed in the tank for 2 hours. It was removed after this period and the particles were washed in running water to remove soluble materials from its surface.

\section{Particle chemical analysis}

The chemical composition of the waste was performed for the treated and untreated particles in hot water of both particle sizes $(0.50$ and $0.85 \mathrm{~mm})$, which were mixed in equal parts and processed into Wiley sawdust. After the classification, the material with 60 mesh 
particle size was selected. The content of each chemical component was expressed on the basis of dry matter. Moisture was determined in each performed test.

For analysis of Klason lignin content (insoluble), the TAPPI 222 om - 02 was used (Technical Association of the Pulp and Paper Industry, 2002a). Klason lignin (soluble) was performed according to procedures described by Novo (2012). The total lignin content was obtained by adding insoluble and soluble lignin. To determine the extractives in hot water, TAPPI 207 om - 99 (Technical Association of the Pulp and Paper Industry, 1999) was followed, while the TAPPI 204 om - 97 (Technical Association of the Pulp and Paper Industry, 1997) was followed for total extractive contents using cyclohexane and ethanol (2:1; v:v), followed by extraction in hot water. Finally, TAPPI 211 om - 02 (Technical Association of the Pulp and Paper Industry, 2002b) was followed for the ash content. Holocellulose content was obtained by the difference [holocellulose $\%=100$ - (total extractives + total lignin + ash in wood)].

\section{Production of panels and determination of compaction ratio}

For the panel production, the particles were oven dried to 3 to $4 \%$ moisture. Urea formaldehyde (UF) resin with a solids content of $64.16 \%$, density of $1.27 \mathrm{~g} . \mathrm{cm}^{-3}$ and $\mathrm{pH}$ of 7.88 was used for bonding the material.

The amount of adhesive to be applied was $10 \%$ solids relative to the anhydrous mass of the particles. The adhesive was homogenized with the catalyst (ammonium sulfate) prior to application at $5 \%$ solids concentration and sprinkled onto the particles. The same procedure was implemented for applying the paraffin emulsion (1\% solids concentration). A rotary drum was used to mix the particles with the catalyst and the paraffin. The particles with the adhesive were deposited inside a $40 \mathrm{~cm}$ x $40 \mathrm{~cm}$ mattress-forming wooden box.

The particle mattress was pre-consolidated in the cold to facilitate loading in the motorized press, where it remained for 10 minutes $(1 \mathrm{~min}$ for closing the plates, 8 min for pressing and $1 \mathrm{~min}$ for opening), at a pressure of $35 \mathrm{kgf.cm}{ }^{-2}$ and temperature of $180^{\circ} \mathrm{C}$, having a nominal thickness of $15.70 \mathrm{~mm}$. The panels were removed from the press, arranged in an upright position to balance the ambient temperature, and then conditioned in an airconditioned room (temperature of $22 \pm 2^{\circ} \mathrm{C}$ and relative humidity of $65 \pm 5 \%$ ) until constant mass.

The nominal density of the produced panels and the basic density of the sugarcane waste particles were $0.65 \mathrm{~g} . \mathrm{cm}^{-3}$ and $0.09 \mathrm{~g} . \mathrm{cm}^{-3}$, respectively, attaining a compaction ratio of 7.22.

\section{Biological resistance of panels to fungi rot attack}

The tests were carried out in order to verify the biological resistance of the particleboard panels in relation to fungi rot attack and to classify them in resistance classes. The requirements of the American Society for Testing and Materials - ASTM D 2017 (American Society for Testing and Materials, 2005) were followed. Two brown-rot fungi, Postia placenta (Fr.) M.J. Larsen \& Lombard (Mad 698) and Gloeophyllum trabeum (Pers.: Fr.) Murr. (Mad 617), and a white rot fungus, Trametes versicolor (L.) Lloyd (Mad 697), obtained from the replating of pure colonies kept by the Biodeterioration and Wood Protection Laboratory, Federal University of Espírito Santo, Jerônimo Monteiro, Espirito Santo, Brazil.

Test pieces with dimensions of $25 \times 25 \times 15.70 \mathrm{~mm}$ (length $\times$ width $\times$ panel thickness) were used, and 18 replicates were used per treatment. The samples were oven dried for 48 hours at $103 \pm 2{ }^{\circ} \mathrm{C}$ to obtain the initial dry mass. B horizon red latosol soil was used with a pH of 6.5 and a water retention capacity of $25 \%$ for the soil-block test.

Glass vials of $600 \mathrm{~mL}$ with screw caps were filled with $300 \mathrm{~g}$ of soil, and $67.00 \mathrm{~mL}$ of distilled water and two feeder strips with dimensions of $3.0 \times 28.0 \times 35.0 \mathrm{~mm}$ (thickness $\times$ width $\times$ length) of Pinus sp. wood were added per bottle. The bottles were autoclaved $\left(121 \pm 2^{\circ} \mathrm{C}, 1.1 \mathrm{kgf}^{\circ} \mathrm{cm}^{-2}\right)$ for 30 minutes, and packed in an incubation room $\left(27 \pm 1^{\circ} \mathrm{C}\right.$ and relative humidity $\left.70 \pm 4^{\circ} \mathrm{C}\right)$ for 24 hours to cool.

After cooling, fungi were inoculated on the feeder strips in a laminar flow hood. Each strip feeder received a $1.0 \mathrm{~cm}^{2}$ inoculum of the fungus to be tested. Two specimens were added to 
each vial and the experiment was incubated under the conditions for 12 weeks. The samples were removed from the bottles, the mycelium removed and soil granules adhered to them.

The samples were again dried in an oven under the same conditions until reaching a constant mass and weighed in a scale $(0.001 \mathrm{~g})$ to obtain the final dry mass. With the data obtained before and after the exposure of the samples to the attack, the mass loss was calculated and the resistance classes of the panels were determined, as recommended by the implemented standard (Table 1).

Table 1. Decay resistance class according to ASTM D 2017 (American Society for Testing and Materials, 2005).

\begin{tabular}{ccc}
\hline Class of resistance & Average residual weight (\%) & Average weight loss (\%) \\
\hline Highly resistant & $90-100$ & $0-10$ \\
Resistant & $76-89$ & $11-24$ \\
Slightly resistant & $56-75$ & $25-44$ \\
Non-resistant & $\leq 55$ & $\geq 45$ \\
\hline
\end{tabular}

Source - ASTM D 2017 (American Society for Testing and Materials, 2005).

Six samples were used for each treatment as an operational mass loss reference, which were maintained under the same conditions but without the presence of fungi in order to determine the mass loss caused by the test conditions (Mendes et al., 2014).

\section{Wettability test}

Samples for the wettability tests had dimensions of $25 \times 25 \times 15.70 \mathrm{~mm}$ (length $\mathrm{x}$ width $\mathrm{x}$ thickness). They were sanded (200 grit sandpaper) on the surface that would receive the solvent droplets to measure the contact angles. A test specimen was collected from each panel to receive the reagent droplets, totaling six angle measurements per treatment.

The solvents used were water and ethylene glycol, as adopted by Oliveira (2013). These solvents have polar characteristics just as the wood surface, and in relation to solvent-wood interactions water may exert the function of a Lewis acid and the ethylene glycol of a base (Walinder \& Johansson, 2001).

For the tests, a $1 \mu \mathrm{L}$ graduated $10 \mu \mathrm{L}$ syringe was placed at a height of $8 \mathrm{~mm}$ in relation to the samples' surface. The drop volume for each solvent was $4 \mu \mathrm{L}$. The contact angle was determined for water and ethylene glycol using the KSV Contact Angle Measurement System software. The angle was obtained by the mean right and left angle for each drop. The photographs had a width of 512 pixels and a height of 480 . Measurements were performed diagonally on each sample surface. The procedure was performed in an environment with a temperature of $20 \pm 2^{\circ} \mathrm{C}$ and $65 \pm 5 \%$ relative humidity.

As indicated by César (2011), two contact angle time measurements were used as a function of the accommodation of the forces that occur over time. To determine the contact time measurements, the solvent was pre-tested and the porous surface of the plates was considered, which facilitated rapid drop absorption. Thus, the time of 0 seconds was set for the initial angle (determined from the drop deposition of the solvent on the sample surface), and the time of 15 seconds was set for the final angle (determined from the contact angle stabilization).

\section{Experimental design}

Sugarcane waste particles submitted or not to treatment in hot water were evaluated for their chemical composition, and descriptive statistics were adopted with the mean and standard deviation being evaluated. The analyses were performed in quadruplicates.

A completely randomized design was used in a $2 \times 2$ factorial arrangement for producing the panels [particle size of the waste particles $(0.85 \mathrm{~mm}$ and $0.50 \mathrm{~mm})$ ] and treating the 
particles (untreated and treated in hot water), Table 2. Three panels were produced for each treatment, totaling 12 units.

Table 2. Experimental treatments performed.

\begin{tabular}{ccccc}
\hline Treatment & Panels & Nominal Density $\left(\mathbf{g} \cdot \mathbf{c m}^{\mathbf{3}}\right)$ & Granulometry $\mathbf{( m m})$ & Particle Condition \\
\hline T1 & 3 & 0,65 & 0.50 & Oven dried \\
T2 & 3 & 0,65 & 0.50 & Treated in hot water \\
T3 & 3 & 0,65 & 0.85 & Oven dried \\
T4 & 3 & 0,65 & 0.85 & Treated in hot water \\
\hline
\end{tabular}

The fungi (two brown rots and one soft rot) and the solvents used (water and ethylene glycol) were then added in order to evaluate the biological resistance of the panels and the wettability. The effects of fungi and solvents were evaluated individually.

For biological resistance, six samples per panel and 18 samples per treatment were tested, while two samples per panel were tested for wettability, totaling six per treatment. The Tukey test was used $(p<0.05)$ for the factors detected as significant by the F-test $(p<0.05)$. Data normality was verified by the Lilliefors test and the homogeneity of the variances by the Cochran test for all cases.

\section{RESULTS AND DISCUSSION}

\section{Chemical analysis of the sugarcane waste particles}

It can be seen (Table 3 ) that there was a change in the average extractive content. The particles treated in hot water showed a reduction corresponding to $53.02 \%$ compared to the control particles.

Table 3. Mean values for contents of totals extractives, soluble lignin, insoluble, ash and holocellulose of the sugarcane waste particles.

\begin{tabular}{ccccccc}
\hline $\begin{array}{c}\text { Treatments } \\
\text { (Particles) }\end{array}$ & $\begin{array}{c}\text { Extractives } \\
\text { totals (\%) }\end{array}$ & Soluble & $\begin{array}{c}\text { Lignin (\%) } \\
\text { Insoluble }\end{array}$ & Total & Ash (\%) & $\begin{array}{c}\text { Holocellulose } \\
\text { (\%) }\end{array}$ \\
\hline T1 & $13.6(1.13)$ & $1.01(0.06)$ & $20.68(0.43)$ & $21.69(0.46)$ & $2.38(0.14)$ & $62.32(2.85)$ \\
T2 & $6.39(0.18)$ & $0.91(0.13)$ & $26.02(0.11)$ & $26.94(1.10)$ & $1.78(0.24)$ & $64.86(1.88)$ \\
\hline
\end{tabular}

T1 - Control particles; T2 - Particles treated by immersion in hot water. Values of the standard deviation between parentheses.

The results obtained are in accordance with the literature. Silva et al. (2011) obtained $2.04 \%$ of extractives for a mixture of solvents, and Qiu et al. (2012) obtained a content of $1.49 \%$ for $95 \%$ ethanol. Furthermore, Pitarelo (2013) obtained an average content of $4.10 \%$ for the solvents ethyl ether, dichloromethane, ethanol:toluene, $95 \%$ ethanol, in addition to hot water, and Soares et al. (2017) obtained a content of $19.59 \%$ for acetone and hot water as solvents.

The difference between the results can be explained by the solvent used, extraction method, type of material, maturity of the raw material and edaphoclimatic factors. It is known that ethanol and toluene extract acids and oxygen compounds, cyclohexane, pigments, oils, waxes and fats, hot water, and polysaccharides. In the present study, toluene was replaced by cyclohexane to meet the laboratory standards where the analysis was performed. The particles treated by immersion in hot water showed a reduction equivalent to $60.69 \%$ (Table 3) in comparison to the control particles.

It is assumed that treating the particles by immersion in hot water removed secondary compounds from the material's structure such as starch and sugar. The reduction of extractives removed corresponded to $46.27 \%$. It is emphasized that for particleboard panel 
production it is desirable that the raw material does not present soluble materials, as these may hinder the bonding process and the biological resistance to fungi. The sucrose concentrations in sugarcane waste are found in amounts ranging from $0.2 \%$ to $5.0 \%$ (Tewari \& Malik, 2007). On the basis of this assertion, there is a great possibility that this sugar has been removed in larger amounts.

The value obtained for total lignin (Table 3) was similar to that reported by Pandey et al. (2000) who obtained an average content of $20.00 \%$, Silva et al. (2011) of $22.80 \%$, Qiu et al. (2012) of $24.81 \%$, Rocha et al. (2012) of $24.70 \%$ and Pitarelo (2013) of $22.82 \%$. The particles treated by immersion in hot water showed higher average values. An inversely proportional relation was observed for extractives and lignin, since as the extractive content decreased, total lignin increased. Higher lignin contents are desirable in producing particulate panels, as this component having a highly condensed structure and an irregular appearance provides high stiffness to the material (Sweet \& Winandy, 1999).

For the ash content, it was observed that the particles treated in hot water obtained a lower percentage value, with reduction equivalent to $25.21 \%$ in relation to the control. The ash content is directly related to the material varieties, fertilization type, growing conditions, growth site and age. It is also affected by impurities (earth and soot) depending on the storage location after the milling process. In this experiment the sugarcane waste particles were submitted to treatment by immersion in hot water and then washing them, which may have contributed to removing the inorganic compounds and residual sucrose from the waste after the milling and extraction process of the sugarcane juice (Pitarelo, 2013).

In the control particles, the ash content obtained was similar to that obtained by Pandey et al. (2000), 2.40\%, Silva et al. (2011), 2.80\%, Qiu et al. (2012), 1.44\%, Rocha et al. (2012), 3.50\% and Pitarelo (2013), 6.72\%.

Some plant species have oxalate, phosphate and silicate crystals, which can bind to the carboxylic acids of the cell wall's chemical components (Sjöström, 1993). These crystals are found in the parenchyma in the form of druses occupying the cellular lumen, and are counted as ashes.

For panels composed of eucalyptus fibers and sugarcane waste, Belini (2012) observed that the percentage increase of waste particles promoted an increase of crystals in the panels, possibly from parenchyma agglomerates present in the waste. In addition, they also observed silica crystals inside the panels, between the sugarcane waste cells. As the particles treated by immersion in hot water had a lower percentage of ash value, it is assumed that some crystals that were adhered to low molecular weight carbohydrates or immersed in the parenchyma were detached.

For the control particles, the holocellulose content (Table 3) was lower than the results reported by Pandey et al. (2000) of 70.00\%, Silva et al. (2011), 74.70\%, Qiu et al. (2012), 63.42\%, Rocha et al. (2012), 71.10\% and Pitarelo (2013) of 70.49\% for the carbohydrate fraction.

\section{Biological resistance of produced panels}

Based on the obtained results (Table 4) and ASTM D 2017 (American Society for Testing and Materials, 2005), the plates of all treatments submitted to the three fungi can be included in the moderate resistance class (Table 4). This classification does not prevent the use of the panels as long as they are not used in humid environments or in direct contact with the soil (Teixeira et al., 1997).

It is observed that $T$. versicolor (white rot) provided a greater general mass loss mean than the fungi causing brown rot ( $P$. placenta and $G$. trabeum). This observation is compatible with Blanchette (2000), who affirms that white rot fungi degrades all primary wood components, including lignin. It was verified that there was no difference between treatments for $P$. placenta fungus (Table 3) for the evaluated factors. In contrast, there were differences for the G. trabeum and T. versicolor fungi, for which the factors were deployed, analyzed and the means were compared (Table 5). 
Table 4. Mean values of mass loss of the particleboard exposed to the fungi $P$. placenta, G. trabeum and $T$. versicolor and respective resistance classes of the panels.

\begin{tabular}{ccccccc}
\hline \multirow{2}{*}{ Treatments } & \multicolumn{7}{c}{ Xylophagous Fungi } \\
\cline { 2 - 7 } & \multicolumn{2}{c}{ P. placenta * } & \multicolumn{1}{c}{ G. trabeum ** } & \multicolumn{2}{c}{ T. versicolor ** } \\
\cline { 2 - 7 } & \multicolumn{1}{c}{ 'WL (\%) } & ${ }^{\mathbf{2}}$ CR & WL (\%) & CR & WL (\%) & CR \\
\hline T1 & $30.09(3,52)$ & ${ }^{3}$ SR & $32.97(2,44)$ & SR & $31.18(3,32)$ & SR \\
T2 & $33.71(3,94)$ & SR & $36.38(2,71)$ & SR & $42.72(4,54)$ & SR \\
T3 & $33.46(3,91)$ & SR & $27.38(2,04)$ & SR & $29.30(3,12)$ & SR \\
T4 & $32.89(3,84)$ & SR & $34.21(2,55)$ & SR & $34.36(3,65)$ & SR \\
Overall average & 32.54 & - & 32.74 & - & 34.39 & - \\
CV (\%) & 11.69 & & 7.45 & & 10.64 & \\
\hline
\end{tabular}

Note: * Not significant and ** significant by F test $(\mathrm{p}>0.05)$. ( ${ }^{1}$ Weight loss $(\%) ;{ }^{2}$ Class of resistance; ${ }^{3} \mathrm{SR}$ : Slightly resistant; $\mathrm{CV}$ : Coefficient of variation.

Table 5. Means tests for the biological resistance of the samples submitted to the attack of G. trabeum and $T$. versicolor, as a function of the granulometry and particle condition.

\begin{tabular}{ccc}
\hline \multirow{2}{*}{ Granulometry } & \multicolumn{3}{c}{ Weight Loss (\%) } \\
\cline { 2 - 3 } & G. trabeum & T. versicolor \\
\hline $0.50 \mathrm{~mm}$ & $34.67 \mathrm{a}$ & $36.95 \mathrm{a}$ \\
$0.85 \mathrm{~mm}$ & $30.79 \mathrm{~b}$ & $31.83 \mathrm{~b}$ \\
\hline \multirow{2}{*}{ Particle condition } & \multicolumn{3}{c}{ Weight loss (\%) } \\
\cline { 2 - 3 } & G. trabeum & T. versicolor \\
\hline Control & $30.17 \mathrm{~b}$ & $30.24 \mathrm{~b}$ \\
Treated & $35.29 \mathrm{a}$ & $38.54 \mathrm{a}$ \\
\hline
\end{tabular}

Note: Means followed by the same letter in the column do not differ (Tukey $p>0.05$ ).

It can be observed (Table 5) that there was a significant increase in the mass loss of the panels constituted with particles having a particle size of $0.50 \mathrm{~mm}$. It is assumed that the more compacted arrangement and absence of voids from the smaller particle sizes facilitated the enzyme translocation by the samples.

It was verified that the plates manufactured with particles treated in hot water (Table 5) had higher degradation levels by the evaluated fungi. It was observed that the $T$. versicolor fungus caused greater mass loss in the samples. These fungi feed on all macromolecular components of lignocellulosic materials, while brown rot fungi have higher affinity for polysaccharides (Zabel \& Morrell, 1992).

Hot water can remove substances such as gums, tannins, sugars, dyes and starch from sugarcane waste (Oliveira et al., 2005). Treating the particles probably extracted some groups of these material compounds related to their biological resistance, which evidences smaller amounts of extractives in the particles treated by immersion in hot water (Table 3).

The lower mass loss percentage obtained for panels produced with control particles was possibly due to the presence of extractives that inhibited fungal attack and which were not removed by the immersion in hot water treatment. Such extractives that function as a protective barrier may have characteristics that prevent the penetration of liquids and the diffusion of enzymes, which may have hampered the degradation of the control panels.

To evaluate the resistance of UF-based adhesive and sugarcane waste panels, Teixeira et al. (1997) tested $G$. trabeum and $P$. sanguineus fungi and obtained mass losses of 42.3 and $43.00 \%$, respectively, and the panels were classified as slightly resistant according to ASTM D 2017. For the durability of panels constituted with eucalyptus and sugarcane waste, adhered with UF-based adhesive with contents of 13 and $16 \%$, and submitted to 
Pleurotus ostreatus fungus attack (white rot), Belini et al. (2014) obtained a mass loss of 32.2 and $41.6 \%$, and the panels were classified as non-resistant, according to AFNOR ENV 12038 (2003).

\section{Contact angle of particleboard panels}

There was no difference between the treatment means (Table 6). For panels made up of untreated particles, the complete removal of extractives could cause an increase in the hydrophobic characteristics of the material, so as to cause greater repulsion of the solvents used (Table 3), however, it was observed that the angles were similar between them.

Table 6. Means values of contact angles obtained with water and ethylene glycol (EG), measured in two periods of particleboard.

\begin{tabular}{ccccc}
\hline \multirow{2}{*}{ Treatments } & \multicolumn{4}{c}{ Contact Angle $\mathbf{(}^{\circ}$ ) } \\
\cline { 2 - 5 } & (Water/initial) & (Water/last) & (EG/initial) & (EG/last) \\
\hline T1 & $114.12 \mathrm{a}$ & $109.73 \mathrm{a}$ & $89.63 \mathrm{a}$ & $85.70 \mathrm{a}$ \\
T2 & $118.64 \mathrm{a}$ & $106.50 \mathrm{a}$ & $87.73 \mathrm{a}$ & $83.65 \mathrm{a}$ \\
T3 & $117.10 \mathrm{a}$ & $108.84 \mathrm{a}$ & $88.08 \mathrm{a}$ & $82.25 \mathrm{a}$ \\
T4 & $109.36 \mathrm{a}$ & $101.51 \mathrm{a}$ & $88.89 \mathrm{a}$ & $81.67 \mathrm{a}$ \\
Overall average & 114.80 & 106.64 & 88.58 & 83.32 \\
CV (\%) & 5.62 & 5.05 & 5.36 & 8.13 \\
\hline
\end{tabular}

Note: Means followed by the same letter in the column do not differ (Tukey $p>0.05$ ).

The surface of all the panels is classified as non-wetting (Table 6) considering the classification of Myers (1999) and according to the angle values (beginning and end) obtained with water. Such classification is explained by the obtained angle values being superior to $90^{\circ}$. For ethylene glycol, the surface of the panels can be classified as partially wetting, since the values ranged from 30 to $89^{\circ}$, with the exception of the T1 treatment referring to the initial angle. It should be noted that the difference was minimal in relation to the other angles.

For panels composed of pine, eucalyptus and sugarcane waste, Oliveira (2013) obtained initial angles with water and ethylene glycol in sugarcane waste panels of $104.42^{\circ}$ and $104.25^{\circ}$, respectively. The difference between the results may have been derived from some parameters that were not specified by the cited author, such as particle size, paraffin presence, syringe height, drop volume and panel pressing parameters.

Due to the appearance of the curves (Figure 1), it is assumed that the volume of the sugarcane waste particles was well compacted and contributed to the density of the outer layers, making them more impermeable, enabling better balance of the solvent drop and hindering the surface wettability.

For this study, sugarcane stems were processed with the husk, which has wax and presents hydrophobic characteristics, and this may have hindered the solvent penetration. Thus, this characteristic may have contributed to the impermeability of the samples and hampered the wettability process. In addition to the wax, the paraffin applied on the panels may also have contributed to increase the waterproofing effect.

The ethylene glycol (Figure 2) had a similar behavior to that of the curves in relation to the angles obtained with water, differing only in relation to the lower angle values obtained. 

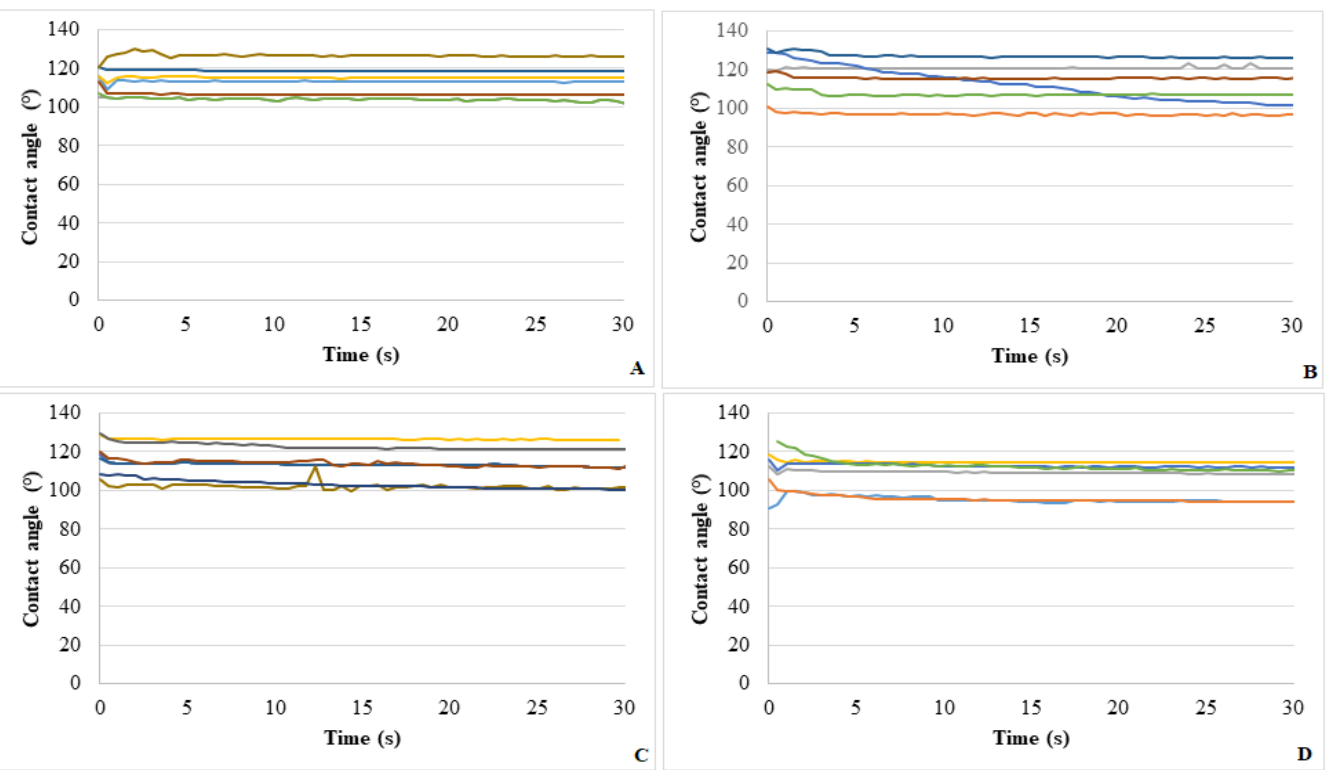

Fig. 1. Evolution of angles obtained with water as a function of time: (A) Particleboard with a particle size of $0.50 \mathrm{~mm}$ (control); (B) Particleboard with a particle size of $0.50 \mathrm{~mm}$ (treated in hot water); (C) Particleboard with particle size $0.85 \mathrm{~mm}$ (control); (D) Particleboard with a particle size of $0.85 \mathrm{~mm}$ (treated in hot water).
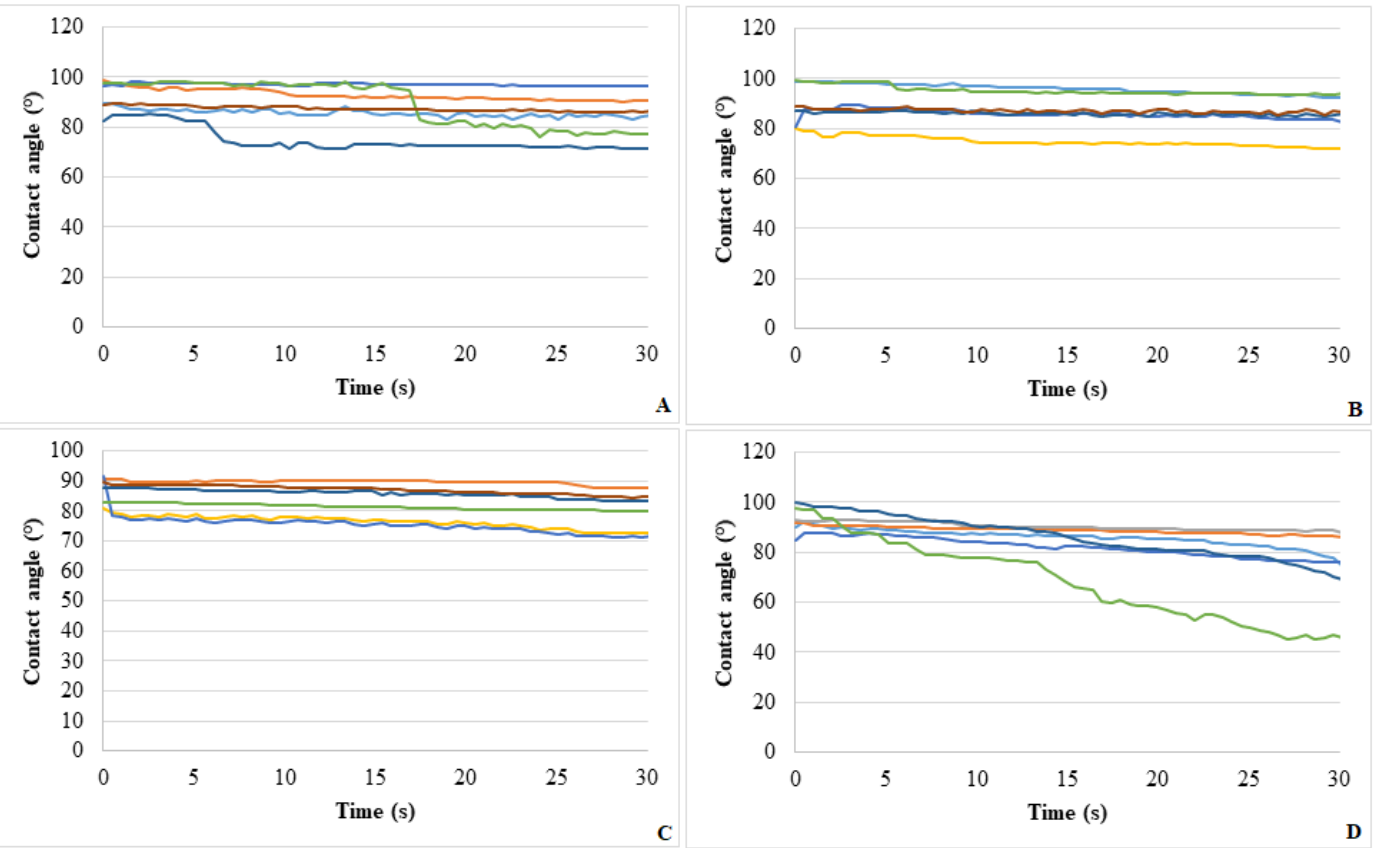

Fig. 2. Evolution of the angles obtained with ethylene glycol as a function of time: (A) Particleboard with a particle size of $0.50 \mathrm{~mm}$ (control); (B) Particleboard with a particle size of $0.50 \mathrm{~mm}$ (treated in hot water); (C) Particleboards with particle size $0.85 \mathrm{~mm}$ (control); (D) Particleboard with a particle size of $0.85 \mathrm{~mm}$ (treated in hot water).

\section{CONCLUSIONS}

The use of hot water as solvent provided greater extractives removal from the particles.

Panels manufactured with $0.85 \mathrm{~mm}$ particle size and not subjected to extraction in hot water were more resistant to the tested fungi causing the brown and white rot. The tested panels were classified as moderately resistant to fungi rot attack.

The tested treatments did not influence the contact angles for water and ethylene glycol and were classified as non-wetting (water) and partially wetting (ethylene glycol). 


\section{REFERENCES}

American Society for Testing and Materials - ASTM. (2005). D-2017: standard method of accelerated laboratory test of natural decay resistance of wood. West Conshohocken: ASTM.

Barros Filho, R. M., Mendes, L. M., Novackc, K. M., Aprelini, L. O., \& Botaro, V. R. (2011). Hybrid chipboard panels based on sugarcane bagasse, urea formaldehyde and melamine formaldehyde resin. Industrial Crops and Products, 33(2), 369-373. http://dx.doi.org/10.1016/j.indcrop.2010.11.007.

Belini, U. L. (2012). Caracterização tecnológica de painéis de fibras da madeira de eucalipto, Eucalyptus grandis, e de partículas do bagaço do colmo de cana-de-açúcar, Saccharum sp (Tese de doutorado). Escola Superior de Agricultura "Luiz de Queiroz", Universidade de São Paulo, Piracicaba.

Belini, U. L., Leite, M. K., Tomazello Filho, M., Chaix, G., Baudasse, C., Lemenager, N., \& Thevenon, M. F. (2014). Bioensaios em painéis confeccionados com eucalipto e bagaço de cana-de-açúcar. Revista Árvore, 38(2), 361-368. http://dx.doi.org/10.1590/S0100-67622014000200017.

Belini, U. L., Tomazello Filho, M., Louzada, J. L. P. C., \& Rodrigues, J. C. (2010). Aspectos anatômicos e tecnológicos de painéis confeccionados com fibras de eucalipto e cana-de-açúcar. Cerne, 16, 48-52.

Blanchette, R. A. (2000). A review of microbial deterioration found in archeological wood from different environments. International Biodeterioration \& Biodegradation, 46(3), 189-204. http://dx.doi.org/10.1016/S0964-8305(00)00077-9.

Bressan Filho, A. (2010). Os fundamentos da crise do setor sucroalcooleiro no Brasil (87 p.). Brasília: Superintendência de Informações do Agronegócio, Companhia Nacional de Abastecimento.

Castro Júnior, S. L., Garzón, N., Williams, D., Guesso, F. L., Savastano Júnior, H., Rossignolo, J. A., \& Fiorelli, J. (2014). Particleboards with agricultural wastes: sugar cane bagasse and reforestation wood. Key Engineering Materials, 600, 667-676. http://dx.doi.org/10.4028/www.scientific.net/KEM.600.667.

César, A. A. S. (2011). Estudo da interação adesivo-partícula em painéis OSB (Oriented Strand Board) (Dissertação de mestrado). Universidade Federal de Lavras, Lavras.

Fiorelli, J., Lahr, F. A. R., Nascimento, M. F., Savastano Junior, H., \& Rossignolo, J. A. (2011). Painéis de partículas à base de bagaço de cana e resina de mamona produção e propriedades. Acta Scientiarum. Technology, 33(4), 401-406. http://dx.doi.org/10.4025/actascitechnol.v33i4.9615.

Fiorelli, J., Sartori, D. L., Cravo, J. C. M., Savastano Junior, H., Rossignolo, J. A., Nascimento, M. F., \& Lahr, F. A. R. (2013). Sugarcane bagasse and castor oil polyurethane adhesive-based particulate composite. Materials Research, 16(2), 439-446. http://dx.doi.org/10.1590/S151614392013005000004.

Hassuani, S. J. (2005). Biomass power generation: sugar cane bagasse and trash (Série Caminhos para a Sustentabilidade, No. 1). Piracicaba: Programa das Nações Unidas para o Desenvolvimento, Centro de Tecnologia Canavieira.

Hernández, R. E., \& Cool, J. (2008). Effects of cutting parameters on surface quality of paper birch wood machined across the grain with two planing techniques. Holz als Roh- und Werkstoff, 66(2), 147-154. http://dx.doi.org/10.1007/s00107-007-0222-4.

Mendes, L. M., Guimarães Júnior, J. B., Santos, R. C., \& César, A. A. S. (2012). Efeito da associação de bagaço de cana, do tipo e do teor de adesivo na produção de painéis aglomerados. Ciência Florestal, 22(1), 161-170. http://dx.doi.org/10.5902/198050985088.

Mendes, R. F., Mendes, L. M., Oliveira, S. L., \& Freire, T. P. (2014). Use of sugarcane bagasse for particleboard production. Key Engineering Materials, 634, 163-171. http://dx.doi.org/10.4028/www.scientific.net/KEM.634.163.

Meschede, D. K., Velini, E. D., Carbonari, C. A., \& Moraes, C. P. (2012). Teores de lignina e celulose em plantas de cana-de-açúcar em função da aplicação de maturadores. Planta Daninha, 30(1), 121-127. http://dx.doi.org/10.1590/S0100-83582012000100014.

Myers, D. (1999). Surface, interfaces, and colloids (519 p.). New York: VCH Publishers. http://dx.doi.org/10.1002/0471234990.

Novo, L. P. (2012). Determinação da relação dos parâmetros de solubilidade de Hansen de solventes orgânicos com a deslignificação organossolve de bagaço de cana-de-açúcar (Dissertação de mestrado). Instituto de Química de São Carlos, Universidade de São Paulo, São Carlos.

Okino, E. Y. A., Alves, M. V. S., Teixeira, D. E., Souza, M. R., \& Santana, M. A. E. (2007). Biodegradação de chapas de partículas orientadas de pinus, eucalipto e cipreste expostas a quatro fungos apodrecedores. Scientia Forestalis, 74(1), 67-74. 
Oliveira, J. T. O., Souza, L. C., Della Lucia, R. M., \& Souza Júnior, W. P. (2005). Influência dos extrativos na resistência ao apodrecimento de seis espécies de madeira. Revista Árvore, 29(5), 819-826. http://dx.doi.org/10.1590/S0100-67622005000500017.

Oliveira, S. L. (2013). Painéis aglomerados de bagaço de cana de açúcar: caracterização visando ao uso na indústria moveleira (Dissertação de mestrado). Universidade Federal de Lavras, Lavras.

Pandey, A., Soccol, C. R., Nigam, P., \& Soccol, V. T. (2000). Biotechnological potential of agro-industrial residues. I: sugarcane bagasse. Bioresource Technology, 74(1), 69-80. http://dx.doi.org/10.1016/S0960-8524(99)00142-X.

Pettersen, R. C. (1984). The chemical composition of wood. In R. Rowell (Ed.), The chemistry of solid wood (pp. 54-126). Washington: American Chemical Society. http://dx.doi.org/10.1021/ba-19840207.ch002.

Pitarelo, A. P. (2013). Produção de etanol celulósico a partir do bagaço de cana pré-tratado por explosão a vapor (Tese de doutorado). Universidade Federal do Paraná, Curitiba.

Qiu, Z., Aita, G. M., \& Walker, M. S. (2012). Effect of ionic liquid pretreatment on the chemical composition, structure and enzymatic hydrolysis of energy cane bagasse. Bioresource Technology, 117, 251-256. PMid:22617034. http://dx.doi.org/10.1016/j.biortech.2012.04.070.

Rocha, G. J. M., Martin, C., Silva, V. F. N., Gómez, E. O., \& Gonçalves, A. R. (2012). Mass balance of pilotscale pretreatment of sugarcane bagasse by steam explosion followed by alkaline delignification. Bioresource Technology, 111, 447-452. PMid:22391588. http://dx.doi.org/10.1016/j.biortech.2012.02.005

Rodrigues, R. C. E., \& Peixoto, R. R. (1993). Avaliação nutricional do bagaço de cana-de-açúcar de micro destilaria de álcool para ruminantes. Revista Brasileira de Zootecnia, 22(2), 212-221.

Silva, A. S., Lee, S. H., Endo, T., \& Bom, E. P. S. (2011). Major improvement in the rate and yield of enzymatic saccharification pf sugarcane bagasse via retreatment with ionic liquid 1-ethyl-3methyimidazolium acetate ([Emim] [Ac]). Bioresource Technology, 102(22), 10505-10509. PMid:21925878. http://dx.doi.org/10.1016/j.biortech.2011.08.085.

Silva, M. R., Pinheiro, R. V., Christoforo, A. L., Panzera, T. H., \& Lahr, F. A. R. (2017). Hybrid sandwich particleboard made with sugarcane, Pinus Taeda thermally treated and malva fibre from Amazon. Materials Research, 21(1), http://dx.doi.org/10.1590/1980-5373-mr-2017-0724.

Silva, V. L. M. M., Gomes, W. C., \& Alsina, O. L. S. (2007). Utilização do bagaço de cana de açúcar como biomassa adsorvente na adsorção de poluentes orgânicos. Revista Eletrônica de Materiais e Processos, 2(1), 27-32.

Sjöström, E. (1993). Wood chemistry: fundamentals and applications (2nd ed., 293 p.). San Diego: Academic Press.

Soares, S. S., Guimarães Júnior, J. B., Mendes, L. M., Mendes, R. F., Protásio, T. P., \& Lisboa, F. J. N. (2017). Valorização do bagaço de cana-de-açúcar na produção de painéis aglomerados de baixa densidade. Ciência da Madeira, 8(2), 64-73. http://dx.doi.org/10.12953/2177-6830/rcm.v8n2p64-73.

Stangerlin, D. M., Melo, R. R., Garlet, A., \& Gatto, D. A. (2011). Durabilidade natural de painéis aglomerados confeccionados com Eucalyptus grandis e Bambusa vulgaris em ensaio de apodrecimento acelerado. Ciência Rural, 41(8), 1369-1374. http://dx.doi.org/10.1590/S010384782011000800012.

Stangerlin, D. S., Costa, A. F., Garlet, A., \& Pastore, T. C. M. (2013). Resistência natural da madeira de três espécies amazônicas submetidas ao ataque de fungos apodrecedores. Ciência da Madeira, 4(1), $15-$ 32. http://dx.doi.org/10.12953/2177-6830.v04n01a02.

Sweet, M. S., \& Winandy, J. E. (1999). Influence of degree of polymerization of cellulose and hemicellulose on strength loss in fire-retardant-treated southern pine. Holzforschung, 53(3), 311317. http://dx.doi.org/10.1515/HF.1999.051.

Technical Association of the Pulp and Paper Industry - TAPPI. (1997). Test methods T 204 om-97: solvent extractives of wood and pulp. Atlanta: TAPPI Techonology Park.

Technical Association of the Pulp and Paper Industry - TAPPI. (1999). Test methods T 207 om-99: Water solubility of wood and pulp. Atlanta: TAPPI Techonology Park.

Technical Association of the Pulp and Paper Industry - TAPPI. (2002a). Test methods T 222 om-02: acid insolub lignin in wood and pulp. Atlanta: TAPPI Techonology Park.

Technical Association of the Pulp and Paper Industry - TAPPI. (2002b). Test methods T 211 om-02: ash in wood, pulp, paper and paperboard: combustion at $525^{\circ} \mathrm{C}$. Atlanta: TAPPI Techonology Park. 
Teixeira, D. E., Costa, A. F., \& Santana, M. A. E. (1997). Aglomerados de bagaço de cana-de-açúcar: resistência natural ao ataque de fungos apodrecedores. Scientia Forestalis, 52, 29-34.

Tewari, J. C., \& Malik, K. (2007). In situ laboratory analysis of sucrose in sugarcane bagasse using attenuated total reflectance spectroscopy and chemometrics. International Journal of Food Science \& Technology, 42(2), 200-207. http://dx.doi.org/10.1111/j.1365-2621.2006.01209.x.

Vital, B. R., Andrade, P. I. L., Carneiro, A. C. O., Cabral, C. P. T., \& Carvalho, A. M. M. (2014). Estabilidade dimensional e resistência a tração perpendicular de painéis fabricados com partículas termorretificadas oriundas de embalagens de Pinus sp. Revista Árvore, 38(5), 951-959. http://dx.doi.org/10.1590/S0100-67622014000500020.

Walinder, M. E. P., \& Johansson, I. (2001).Measurement of wood wettability by the Wilhelmy method. Part 1. Contamination of probe liquids by extractives. Holzforschung, 55, 21-32, https://doi.org/10.1515/HF.2001.005.

Zabel, R. A., \& Morrell, J. J. (1992). Wood microbiology: decay and its prevention (476 p.). San Diego: Academic Press.

Authors' contributions: FMSB: Data curation, formal analysis, investigation, methodology, project adminisitration, validation, visualization, writing - original draft, writing - review \& editing; GBJ: conceptualization, project adminisitration, resources, supervision; JBP: investigation, methodology, resources, supervision, writing review \& editing. 